\title{
Investigating the relationship between earnings quality, audit quality and capital cost despite Iran's economic sanctions in Tehran Stock exchange
}

Hamid Reza Kordlouie

Associate Professor and Member of Department the Accounting, and Member of the Young Researchers and Elite Club, Islamshahr Branch, Islamic Azad University, Iran hamidreza.kordlouie@gmail.com

Leila Sadeghi

PhD student, Islamic Azad University, Science and Research Branch (Qeshm International Branch), Iran

leila_sadeghi4712@yahoo.com

Nahid Sadeghi

PhD student, Islamic Azad University, Science and Research Branch (Qeshm International Branch), Iran

Nahid_sadeghi@yahoo.com

\section{Editor Científico: José Edson Lara}

Organização Comitê Científico

Double Blind Review pelo SEER/OJS

Recebido em 06.09.2018

Aprovado em 25.10.2018

\section{(c) $(1)(9$}

Este trabalho foi licenciado com uma Licença Creative Commons - Atribuição - Não Comercial 3.0 Brasil 


\begin{abstract}
The purpose of this study is to investigate the effect of earnings quality and audit quality on capital costs during the sanctions in Tehran Stock Exchange companies. In order to achieve the research objectives, the information of the companies accepted in the Tehran Stock Exchange was used during a 7-year period (2009-2015). In this research, the audit quality was assessed using two criteria of the size of the audit firm and the continuity of the audit firm's cooperation with the owner. In order to calculate the cost of capital from the ratio of earning to the adjusted price of the industry and for the earning quality, the equation introduced by Freeman et al. 1982 has been used. The research hypotheses have been tested using the combined regression analysis. The results showed that the size of the audit firm and the continuity of cooperation between the audit firm have a reverse and significant relationship with the cost of capital. So, it can be concluded that the audit quality will reduce the cost of capital. Also, with the increase in the earning quality, the cost of capital decreases. This result suggests that the earning quality is an effective and meaningful factor in reducing or increasing the cost of capital companies. On the other hand, the sanctions imposed in 2010 did not affect the variable of capital cost.
\end{abstract}

Keywords: Capital Cost, Earnings Quality, Audit Quality, Economic Sanctions

\title{
Investigando a relação entre a qualidade dos lucros, a qualidade da auditoria e o custo de capital, apesar das sanções econômicas do Irã na Bolsa de Valores de Teerã
}

\section{Resumo}

O objetivo deste estudo é investigar o efeito da qualidade dos lucros e da qualidade da auditoria nos custos de capital durante as sanções nas empresas da Bolsa de Valores de Teerã. Para atingir os objetivos da pesquisa, as informações das empresas aceitas na Bolsa de Valores de Teerã foram utilizadas durante um período de 7 anos (2009-2015). Nesta pesquisa, a qualidade da auditoria foi avaliada usando dois critérios do tamanho da firma de auditoria e a continuidade da cooperação da firma de auditoria com o proprietário. Para calcular o custo de capital da relação entre o ganho e o preço ajustado da indústria e para a qualidade do ganho, a equação introduzida por Freeman et al. 1982 foi usado. As hipóteses de pesquisa foram testadas usando a análise de regressão combinada. Os resultados mostraram que o tamanho da firma de auditoria e a continuidade da cooperação entre a firma de auditoria têm relação reversa e significativa com o custo de capital. Assim, pode-se concluir que a qualidade da auditoria reduzirá o custo do capital. Além disso, com o aumento da qualidade dos ganhos, o custo do capital diminui. Este resultado sugere que a qualidade do ganho é um fator efetivo e significativo na redução ou aumento do custo das empresas de capital. Por outro lado, as sanções impostas em 2010 não afetaram a variável custo de capital.

Palavras-chave: Custo de Capital, Qualidade do Resultado, Qualidade da Auditoria, Sanções Econômicas 
Investigando la relación entre la calidad de las ganancias, la calidad de la auditoría y el costo de capital a pesar de las sanciones económicas de Irán en la Bolsa de Teherán

\section{Resumen}

El propósito de este estudio es investigar el efecto de la calidad de las ganancias y la calidad de la auditoría en los costos de capital durante las sanciones en las empresas de la Bolsa de Teherán. Para lograr los objetivos de la investigación, la información de las empresas aceptadas en la Bolsa de Teherán se utilizó durante un período de 7 años (2009-2015). En esta investigación, la calidad de la auditoría se evaluó utilizando dos criterios del tamaño de la firma de auditoría y la continuidad de la cooperación de la firma de auditoría con el propietario. Con el fin de calcular el costo de capital a partir de la relación entre la ganancia y el precio ajustado de la industria y por la calidad de la ganancia, la ecuación introducida por Freeman et al. 1982 se ha utilizado. Las hipótesis de investigación se han probado utilizando el análisis de regresión combinada. Los resultados mostraron que el tamaño de la firma de auditoría y la continuidad de la cooperación entre la firma de auditoría tienen una relación inversa y significativa con el costo del capital. Por lo tanto, se puede concluir que la calidad de la auditoría reducirá el costo del capital. Además, con el aumento de la calidad de la ganancia, el costo del capital disminuye. Este resultado sugiere que la calidad de la ganancia es un factor efectivo y significativo para reducir o aumentar el costo de las compañías de capital. Por otro lado, las sanciones impuestas en 2010 no afectaron la variable de costo de capital.

Palabras clave: costo de capital, calidad de los ingresos, calidad de la auditoría, sanciones económicas

\section{Introduction}

Since the victory of the Islamic Revolution, four rounds of sanctions have been imposed on the country. The first round was experienced in 1978-1979 when it was forbidden to export Iranian food and medicine to Iran at the time when the Iranian government seized the assets of American banks. In addition, Americans have been banned from any financial deal with Iranians, and the United States banned all imports from Iran and all travels to Iran. Also, all military equipment purchased or ordered by the Iranian government was also seized. The second round coincided with the Iraqi military invasion of Iran, which was far from sanctions, mostly during the 1983-1995. Extreme tightening of the first round of sanctions on the export of military equipment by dual use to Iran, ratification of the ban by the US Congress on the export of American products to Iran, the prohibition of any deal for the development of the oil industry in Iran, the ban on imports, exports and mutual investment between the major Second round sanctions. The third round of Iran and the United States, the adoption of the Demento law and the imposition of sanctions began in 1996. The enactment of the Iran and Libya sanctions law lists the names of Iranian banks and some of the institutions and companies 
affiliated to the Islamic Revolutionary Guards Corps (IRGC) in the list of sanctions, the most important of which has been the elimination of sanctions by 2004 .

In the fourth round of sanctions, which since December 2010 aims to reduce the speed of growth. The sanctions of Iranian oil exports, the sanctions imposed by the Central Bank of the Islamic Republic of Iran, and the intensified embargo on imports of essential goods are the most important sanctions. (Garshabi et al., 2016) Therefore, in this study, considering that the data of stock companies for the years 2009-2014 will be examined, we will only examine the effect of a sanction, the most basic sanction in 2010 .

On the other hand, given that stock companies were also affected by these sanctions, they would have an impact on key variables, including capital costs.

Given the low level of information risk presented in the information provided or the inability of the information to be expected in estimating expected earning, it is expected that the earnings quality will negatively affect the cost of capital to the extent that the estimation of the expected returns of investors and stakeholders is uncertain. (Francies, 2003) Since the cost of capital is based on investors' expected earning, they are associated with the amount of risk they have accepted. Shareholders rely on company's financial statements, in particular, reported earnings, to determine their expected return on equity. Therefore, reported earnings quality is effective on estimating the expected returns of the shareholders and determining the company's cost of capital. In this research, the relationship between cost of capital and earnings quality with the comparative approach of high-quality companies and low-earning companies in Tehran Stock Exchange has been tested experimentally. Therefore, in order to increase the quality of work and maintain the independence of the audit firms, different approaches have been proposed by professional authorities and professional advisers, one of the recommendations they recommend is the periodic change of audit institutions.

According to the presented explanations, this study aims to investigate the effect of earnings quality and audit quality on capital costs in terms of recent economic sanctions. In fact, this research seeks to answer the question of whether the earnings quality and audit quality with the cost of capital in affiliated companies in the Tehran Stock Exchange affect Iran's economic sanctions? 


\section{Literature and Research History}

Experimentally, professional and high-level auditors in different industries have limited roles in discretionary accruals to keep their professional accreditation and professional reputation and prevent their litigation as respondent (Defond et al., 2000). As auditors specialize in industries, their specialized knowledge increases and they are expected to be more watchful in recognizing unlawful reports comparing to unspecialized auditors (Bensin et al., 2003) . Krishnan (2003) measured the relationship between specialization in industrial auditing and discretionary accruals and found their negative relationship. Cost of capital plays a fundamental role in investment and financial supply decisions. Cost of capital is defined conceptually related to expected return. In other words, Cost of capital is the minimum expected rate of return. If the expected return is less than cost of capital, the value of economic unit will decrease; therefore, managers must extend the expected rate of return to the cost of capital in order to keep the value of economic unit; during which the key factor is decreasing cost of capital. As the cost of capital is based on investors' expected rate of return, it is relate to accepted risk (earning changes) (Sofiani, 2005). Firms are going to provide qualitative information in order to enhance cash flow prediction and decrease data risks (Ardestani, 2007).

The cost of capital is the weighted average of provided resources cost by investments and debts. As the cost of financing by debts (interest rate) is not competitive in Iran and determined through banking system and orders, the cost of capital is focused among the elements of cost of capital.

Audit profit and its elements are the information considered by people while making decisions. Investors search their benefits in earning information. Accounting profit is the sign of changing investors believes and behaviors. Evidences indicate that accounting profit is a good index for stock returns and predicting cash flow. However, some analysts concluded that economic earning is better index for predicting cash flow than accounting profit because of conservatism limitations and its importance in determining accounting profits. Economic earning was defined Smith firstly and then expanded by Hix. He defined the earning as an amount spent by a person for a period and has the same welfare at the end of this period like its starting point (Osmani, 2002).

The quality of information must make assessing the past performance possible and be effective in measuring profitability and predicting future activities in order to make the reported earning useful in measuring firms' performance and profitability and reliable for investors and beneficiaries. Therefore, the digit of reported earnings is important for investors and effective 
on their decisions. In addition to, the quality of earning is a dimension of earning information for investors.

The quality of earning is a concept with different aspects. So that, there are various definitions and measurement dimensions for this issue and some of important ones are as follows:

Soo Young Kwon (2010) recommended the change in audit firms as an effective factor in audit quality. His research was aimed at examining the impact of change in audit firms on auditors' hours of work, audit fees and audit quality. In this study, he concluded that the change in audit firms would increase the hours of audit work and increase auditors' return. Also, the quality of the audit remained unchanged, even had been decreased in some cases.

According to Dan Li (2010), auditors have a certain sense of loyalty in long-term audits, which in turn challenges the auditor's ability to conduct a high- quality and effective audit. He also conducted a research on the length of the relationship between the client auditor and his relationship with conservative reporting that this is a positive relationship with large companies as well as the companies controlled by the auditor, but this relationship is negative for companies that are where do not care by the auditors.

Zengin and Ozkan (2010) investigated the relationship between audit quality and earnings management in interim financial statements using 2,252 quarterly quarterly corporate observations for the years 2009 to 2006. They found that the 4 largest auditors, industry expertise and corporate affiliations Audit (as an audit quality indicator) limits the voluntary accruals (an indicator for earning management).

Wuchun Chi and colleagues (2011) examined the relationship between advanced audit quality and actual earning management in 1800 companies over the period from 2002 to 2010, they first found out that auditors wiith more expertise and large auditors ( $\mathrm{N}$ large) found more remuneration to other auditors. They also concluded that auditors specializing in industry and large auditors would have limited actual earning management, and that high-level auditors had a positive relationship with the actual earnings management, and the auditor's change could lead to less earning management.

Janjani (2011) in a study entitled the relationship between earnings and its components with stock returns with ermphasis on earnings quality in companies accepted in tehran stock 
exchange, to examine the relationship between earning and its components with stock returns with an emphasis on the quality of earnings of accepted companies. In order to investigate this issue, a sample of 230 companies from listed companies in tehran stock exchange has been selected for the period of 7 years between 2002 and 2008. The results based on the panel date method indicate that the components of the earning both have information content, but the earnings cash component is more informative than its commitment component. Also, the results of this research show that high earnings companies have positive returns and low-earning companies have a negative earning margin, so that the companies that have the highest quality earnings were $17 \%$ more likely to be in the survey period than those with the lowest profitabiity.

Nonahal et al. (2010) examined the relationship between audit quality and accruals reliance over the years 2001 to 2007. The results of this study show that audited companies are of higher quality than those audited by a low quality auditor has a higher coefficient of sustainability of accruals and therefore has the high accruals reliance.

Namazi et al. (2011) examined the relationship between audit quality and earnings management by using 61 views from 2001 to 2007 . The results show that there is no relationship between auditor's size and earnings management, but there is a positive and significant relationship between the period of auditor and earning management.

It should also be noted that the difference between the present research and other studies is that in the present study two important criteria of audit quality called company size and audit tenture have been used simultaneously, which is not the case in this research, and also in this research the effect of the sanctions has also been measured, which has not been the case in the research.

\section{Research Hypotheses}

In order to achieve the objectives of the research, the following hypotheses have been formulated:

First Hypothesis: there is a negative and significant relationship between capital cost and earnings quality.

Second hypothesis: There is a negative and significant relationship between cost of capital and audit quality.

Third hypothesis: There is a negative and significant relationship between cost of capital and economic sanctions. 


\section{Material and Methods}

This research is applied in term of purpose. Also, the nature of this research is descriptive of correlation type. Also, in terms of information gathering, post-event research is a descriptive, inferential, and multivariate combined regression analysis to analyze information. The research hypothesis has been tested based on combined data and also the effect of quality of earning and audit quality on the cost of capital with the virtual variable of the sanction period. The variables of the model are based on the model of Stakes et al. (2009), Francies et al. (2005) and Hajih and Sobhani. (2013) Eviews software is also used to calculate and process variables.

\section{Society, Statistical sample and Research Period Community and Statistical sample}

The statistical population of this research consisted of all companies accepted in Tehran Stock Exchange. The statistical sample for the years 2009-2015 was selected based on the following conditions:

1. The name of the company is included in the list of companies accepted on the Stock Exchange on 14/03/2009.

2. End of fiscal yea ending March. Also, during the research period, the companies did not change their fiscal year.

3. The statistics and information about variables and explanatory notes of financial statements are available.

4. Do not stop trading more than three months.

5. Research is conducted for non-financial companies. Therefore, banks and all investment companies, leasing companies and financial institutions were excluded from the sample.

Among the reasons for the elimination of companies and financial institutions:

A) There is a difference in the interpretation of financial risk (high leverage ratios) in financial and non-financial companies, so that this risk may seem abnormal for financial companies, as well as for non-financial corporations, and result in inappropriate decisions. 
B) There is a difference in the methods and estimates of accounting in financial and non-financial companies that their interference with each other may result in incorrect results.

C) Non-transparency of classification between operational activities and financing of financial and non-financial companies.

Due to the limitations mentioned above, 50 companies were selected as an accessible sample during a 14-year period.

\section{Statistical Research Model:}

In order to test the hypothesis of the research, regression analysis based on statistical model is used as follows. Also, the effect of quality of earning and audit quality with the virtual variation of the sanction period on the cost of capital has been tested.

$\mathrm{EP}_{\text {j.t }}=\beta_{0}+\beta_{1}(\text { Adult-tenure })_{j . t}+\beta_{2}($ Audit-size $)$ j.t $+\beta_{3}\left(\mathrm{SIZE}_{\mathrm{j} . \mathrm{t}}\right)+\beta_{5}(\mathrm{EQ}$ j.t $)+\beta_{4}\left(\mathrm{DEBT}_{\mathrm{j} . \mathrm{t}}\right)+$ $\beta_{4}\left(D_{\text {Embargo j.t }}\right)+\beta_{4}\left(B . M_{j . t}\right)+€_{j . t}$

Equation (1)

EQ: Quality of earning in year $_{\mathrm{t}}$

EP: The cost of company ${ }_{j}$ capital in year ${ }_{t}$

(Audit-size): Audit size of company ${ }_{\mathrm{j}}$ in year $_{\mathrm{t}}$

(Adult-tenure): Auditor's expertise in the industry of ${ }_{\mathrm{j}}$ in year $\mathrm{t}_{\mathrm{t}}$

SIZE: (size) The natural logarithm of the total assets of the company ${ }_{j}$ in year ${ }_{t}$

B.M: The ratio of the book value of shares to the stock market value of the company ${ }_{i}$ in year ${ }_{t}$

DEBT: Debt to total assets of company $\mathrm{j}_{\mathrm{j}}$ in year ${ }_{\mathrm{t}}$

$D_{\text {Embargo j.t }}=$ The virtual variable of sanction will be zero for the years 2009 and 2010, and is one for 2010 and later. 


\section{Variables and Calculaion Method}

\section{Dependent Variable: Cost of Capital}

In order to calculate the cost of capital, the ratio of earning to the adjusted industry price is used, which is calculated as follows. The ratio of earning to the price of company $\mathbf{J}$ in year $\mathrm{t}$ is the mid-earning for the industry (from the mid-earning to the price of each industry in the sample) This is the ratio of the index of measuring the dependent variable of the research, ie the cost of capital.

\section{Independent Variables:}

\section{Earning Quality:}

Stability of earning is one of the criteria for earning quality. Stability of earning means the continuation of current earnings. The higher the earningability of the earning, the assumed the quality of the reported earnings is higher. To measure earning stability, the present study uses the equation introduced by Titman et al. 1982 in which the Earningt coefficient in the following equation shows the earning stability 1 , that is, alpha 1 , to 1 , so that the closer the coefficient is to one, stability of earining is higher (higher earnings quality).

Earning ${ }_{t+1}$ 01Earning $\mathrm{V}_{\mathrm{t}}$

Equation (2)

Which we have in the equation above:

Earning $_{\mathrm{t}}$ indicates earning before long-term accruals in year $\mathrm{t}$.

\section{Audit quality:}

In this research, the quality of the audit is measured using the two criteria of the size of the audit firm and the continuity of the audit firm's cooperation with the client.

1. Audit size: The size of the audit and the quality of the work of the audit firms are different from each other and researchers use substitutes to distinguish between high-quality audit firms and low-quality audit firms. The size of the auditing institutions, the age and the name of the institutions are examples of distinctive criteria, that is, larger institutions with a more well- 
known brand have not been superior to other institutions with higher quality work. (De Angelo, 1981, pp. 189-183)

An indicator of the quality of the audit is the size of the audit firm, which is in direct relationship with each other so that the larger the audit firm's size, the higher the audit quality. In this research, the size of an audit firm is known as Audit Firm (Brand). As a result of the reputation of the Audit Firm, the credibility of the financial statements has increased, and therefore the quality of the audit will be higher. (Chen et al. 2005; De Angelo, 1981)

In order to measure the size of the audit firm, the audit firms should be the member of the public accountant's community as the small auditing bodies and the audit firm due to the large number of employees and more senior institutions as large auditing institutions. To measure this variable, if the audit firm is selected as the auditor of the company, it is 1 and otherwise 0 .

2. Audit -tenure: In this research, market share is used as an indicator for the specialty of the auditor industry, since it shows the industry's priority over other auditors. The higher the auditor's market, the higher the industry expertise and auditor experience than other competitors. Having a high market share also points out that the auditor has successfully distinguished himself / herself from other competitors in terms of audit quality.

The market share is calculated as follows: "The total net book value of the clients' assets of the audit firm in that industry is divided by the total ROI of the assets of all its auditors".

In this research, market share is used as an indicator for measuring the expertise of the audit industry. Having a large share of the market or dominant market share also points out that the auditor has successfully distinguished himself from other competitors in terms of audit quality. (Mi Ho and Velenkis, 2002) In order to calculate market share in this research, the example of Palm Rose (1981) is adopted and the market share of auditors is calculated as follows:

(Total assets of all the owners of each particular audit firm in the particular industry) divided by (total assets of all owners in the industry)

The institutions in this research are considered as industry experts whose market share; i.e. above-mentioned equation is more than (1.2) of existing companies in an industry (Heydari et al., 2015)

Control variables: In this research, in order to increase the accuracy and reliability of the reliance on the results and control of the various symbols, the risk affecting the cost of capital based on previous research, three variables of the size of the company, the ratio of book value to market value and the debt ratio are considered as control variables. The size of the 
company is considered as an alternative to the information environment. To control the effect of the company's investment opportunity set on capital costs, the ratio of book value to market value has been used. Usually this ratio is an indicator for the company's growth opportunity. The difference in market value and book value can be attributed to the existence of intangible assets in the company. The ratio of debt to assets is one of the measures to measure the financial leverage of a company. The size of the company is equivalent to the logarithm of the book value of the company's assets and the ratio of book value to market value is defined as the ratio of the book value of the company's stock to its market value. The ratio of debt to assets is obtained by dividing the total debt of the company into total assets.

\section{Results}

\section{Descriptive Statistics of Research Variables:}

Table 1, shows the size of the descriptive statistics indexes used in the research for selected companies.

\section{Table 1}

Results of descriptive statistics of the variables of the research.

\begin{tabular}{|l|c|c|c|c|c|}
\hline \multicolumn{1}{|c|}{ Earning quality } & Mean & $\begin{array}{c}\text { Standard } \\
\text { Deviation }\end{array}$ & Variance & Skewness & Kurtosis \\
\hline The size of the audit firm & 0.892 & 7.26 & 52.7 & 8.35 & 121.2 \\
\hline Size of the company & 0.42 & 0.22 & 01.030 & 1.448 & 5.575 \\
\hline $\begin{array}{l}\text { Book value ratio to market } \\
\text { value }\end{array}$ & 5.746 & 0.618 & 0.382 & 1.123 & 1.753 \\
\hline Debt ratio of auditor & 0.640 & 0.608 & 0.370 & 1.926 & 5.051 \\
\hline $\begin{array}{l}\text { Continuity } \\
\text { selection }\end{array}$ & 1.069 & 0.49 & 0.24 & 5.65 & 65.8 \\
\hline Earning quality & 0.471 & 0.50 & 0.25 & - & - \\
\hline The size of the audit firm & 6.086 & 4.47 & 16.17 & 5.123 & 24.753 \\
\hline
\end{tabular}

\section{Examinations Related to the Research Model:}

\section{Validity and Reliability of Data}

Since the data used in this research is of a kind of secondary and quantitative data collected from sites linked to the Stock Exchange and prepared according to the standards of that organization, their validity is confirmed. Panel root test was used to measure the stationary 
of panel data. Before estimating the model, it should be noted that due to the low period of time, unit root tests in panel data are not used to ensure the reliability of the variables, but to better determine the existence of a long-term relationship was discussed whether There is a long-term relationship with the false regression problem that the zero hypothesis is based on the lack of a long-term relationship and a Newey-West test is used. Because the level of significance for the long-term relationship is less than zero, therefore, they have a long-term relationship.

Table 2

Long-Term Relationship Test

\begin{tabular}{|c|c|}
\hline Newey-West & Significant level \\
\hline-8.3 & 0.0000 \\
\hline
\end{tabular}

\section{Correlation Test of Research Variables}

Table 3

Correlation Coefficients Between Research Variables

\begin{tabular}{|l|c|c|c|c|c|c|}
\hline Research variable & 1 & 2 & 3 & 4 & 5 & 6 \\
\hline Earning quality & 1 & & & & & \\
\hline The size of the audit firm & 0.23 & 1 & & & & \\
\hline Size of the company & 0.51 & 0.53 & 1 & & & \\
\hline $\begin{array}{l}\text { Book value ratio to market } \\
\text { value }\end{array}$ & 0.41 & 0.33 & 0.24 & 0.44 & 1 & \\
\hline $\begin{array}{l}\text { Debt ratio auditor } \\
\text { Continuity of } \\
\text { selection }\end{array}$ & -0.36 & 0.23 & 0.29 & 0.33 & 0.26 & 1 \\
\hline
\end{tabular}

The negative sign for correlation also indicates that the relationship between the two variables is inverse and if the correlation between research variables is less than 0.07 , then it can be stated that there is no linearity between the variables.

\section{Heterogeneity of Variance Testing}

For the GLS heterogeneity of variance, the Pagan test is used to estimate. The results are presented. 


\section{Table 4}

The Results of the Heterogeneity of variance

\begin{tabular}{|c|c|c|}
\hline $\begin{array}{c}\text { Estimation } \\
\text { Method }\end{array}$ & Significant Level & $\begin{array}{c}\text { Test } \\
\text { Statistic }\end{array}$ \\
\hline Ols & 0.32 & 1.75 \\
\hline
\end{tabular}

As shown in the table above, Pagan test results show that the research hypothesis model has a significant level of more than $5 \%$ and therefore the zero assumption based on the homogeneity of variance is accepted, and the OLS regression model is used for estimating hypotheses models.

\section{Fixed or Random Effects Test}

The results of the F-Limer test are as follows:

The hypothesis is zero and the opposite of this test is as follows:

$\mathrm{HO}=$ Uniform units are homogeneous (OLS Method)

$\mathrm{H} 1$ = FE Units are not homogeneous (Fixed effects)

Given that the F test statistic and Chi-square is very high, the value of probability is also less than $5 \%$ for both, so we reject the zero hypothesis in favor of the opposite hypothesis for use of the FE as an appropriate method.

\section{Table 5}

The Results of F Limer Test

\begin{tabular}{|c|c|c|}
\hline Test & $\begin{array}{c}\text { Test } \\
\text { Statistic }\end{array}$ & $\begin{array}{c}\text { Significant } \\
\text { Level }\end{array}$ \\
\hline F-Limer Test & 1.43 & 0.0005 \\
\hline
\end{tabular}

The results of the $\mathrm{F}$ limer test indicate that the similar constant is rejected for all companies surveyed at a significant level of 5\% and the panel data method can be used to estimate the model. In the following, by using the Hausman test, a suitable method is chosen between the method with constant and random effects for estimating the model. The results of the Hausman test are reported in the following table: The hypothesis is zero and the Hausman test is as follows. 
$\mathrm{H} 0=\mathrm{RE}$ There is no correlation between disturbance components and explanatory variables random effects

$\mathrm{H} 1=\mathrm{FE}$ There is correlation between disturbance components and explanatory variables. Fixed effects method

Based on Hausman's test results, it is seen that the zero hypothesis is rejected in favor of the opposite hypothesis; therefore, the method used to estimate our function is the FE method.

\section{Table 6}

The Results of the Hausman Test to Select the Appropriate Method

\begin{tabular}{|l|l|}
\hline Chi-Square & Significant Level \\
\hline 6.59260 & 0.01590 \\
\hline
\end{tabular}

The results of the above table indicate that the zero hypothesis based on the choice of the method with random effects is rejected for estimating the model at a significant level of 5\%. Therefore, a constant-effect method can be used to estimate the model.

\section{Testing the Reliability of the Residual}

Table 7

Reliability for residual

\begin{tabular}{|c|c|c|c|}
\hline \multirow{2}{*}{ Statistic } & \multicolumn{3}{|c|}{ Critical Value } \\
\cline { 2 - 4 } & $1 \%$ & $5 \%$ & $10 \%$ \\
\hline-2.180 & -2.57 & -1.94 & $1.6-$ \\
\hline
\end{tabular}

Given that the value of the Dickey Fuller statistical equation is greater than the critical value at a level of $5 \%$, it can be concluded that the term residual or pattern error is stationary at all levels of and is a real regression.

\section{5- Estimation of the Research Model:}

The results of the research model using the composite regression in Table (8) are as follows: 


\section{Table 8}

Estimation of Composite Regression Model

\begin{tabular}{|c|c|c|c|c|}
\hline $\begin{array}{l}\text { The name of the variables } \\
\text { dind }\end{array}$ & Coefficien & $\begin{array}{l}\text { Standard } \\
\text {. }\end{array}$ & Statistic $\mathrm{t}$ & Significant Level \\
\hline Constant & 1.732 & 0.89 & -2.105 & 0.0363 \\
\hline Earning quality & $0.0025-$ & 0.00105 & -2.56 & 0.0312 \\
\hline Company size & 0.3235 & 0.1504 & 2.150 & 0.0326 \\
\hline Book value to market & 0.02947 & 0.0735 & 0.408 & 0.723 \\
\hline Debt ratio & 0.05617 & 0.1972 & -2.84 & 0.0048 \\
\hline Virtual variable of Sanction & 0.0335 & 0.0647 & 0.51 & 0.6047 \\
\hline The size of the audit firm & -0.0561 & 0.1972 & -2.84 & 0.0048 \\
\hline Continuity of auditor selection & -0.2351 & 0.0817 & -2.87 & 0.0044 \\
\hline $\begin{array}{c}\text { Modified determination } \\
\text { coefficient }\end{array}$ & 0.6417 & \multicolumn{2}{|c|}{ determination coefficient } & 0.6730 \\
\hline Fisher statistics & 6.560 & \multicolumn{2}{|c|}{ Durbin-Watson } & 1.89 \\
\hline Significant level & 0.000000 & & & \\
\hline
\end{tabular}

In the table above, the effect level and significance level of each of the variables indicate that all the variables considered are significant except for the book value to the market and the virtual variables of sanction. Also, the variables of the earnings quality, the size of the institution and the continuity of the institution have a negative effect and the variables of the size of the company and the ratio of debt have a positive and significant impact.

The coefficient of determination is $67 \%$. It shows that a few percent of the changes in accruals management are explained by the variables entered in the model. In order to study the overall significance of the model, we use the F statistic considering that the significance level is zero and the overall model is confirmed. Moreover, since the Durbin-Watson is 1.89 , and if the Durbin-Watson is between 1.5 and 2.5, the model does not have autocorrelation problem.

\section{Discuson and conclusions}

\section{The Result of First Hypothesis:}

In the first hypothesis, it is stated that there is a negative and significant relationship between capital cost and high earnings quality. Regarding the coefficients of earnings quality in the regression model of research $(0.0025)$ and its probability $(0.031)$ indicates that the first hypothesis is accepted at $95 \%$ confidence level; in other words, by increasing the earnings 
quality of companies accepted in Tehran Stock Exchange, the capital cost declines. This result indicates that the earning quality is an effective and meaningful factor in reducing and increasing the cost of capital companies. By applying changes in the earning quality, it is possible to manage and control the cost of corporate capital, and the results of this research are similar to the results of Niko Maram and Amini (2011).

\section{Result of The Second Hypothesis:}

In the second hypothesis it is stated that "there is a negative and significant relationship between capital cost and audit quality. »

The relationship between audit quality and cost of capital showed is a reverse and significant relationship, and companies that use large auditing firms have lower cost of capital. As larger audit firms are interested in gaining more reputation in the market, these institutions provide better quality audit services because they have more resources and facilities to train and perform different tests. The results of this study are similar to Frnado (2008) and Monssy et al. (2004). Also, there is a significant and inverse relationship between continuing collaboration and capital costs. Therefore, the continuation of cooperation with the audit firms and audit quality will improve companies that maintain their relationship with institutions likely to be less expensive than other institutions. The results of the investigation are the same as Frnado et al. (2008) and Jackson et al (2007).

\section{Result of Third Hypothesis:}

In the third hypothesis, there was a negative and significant relationship between capital cost and economic sanctions.

The results of the model showed that the value is more than five hundredth, so there is no significant effect. The positive trend of the stock exchange in the days when the stock market was adopted against the Security Council resolutions adopted in Iran in 2010, indicated that the sanctions had no effect on the stock market. The capital market has enjoyed a wide range of diverse industries, with a high degree of solidity, so that, regardless of the political resolutions against Iran, its path and the upward trend of the market and index growth after the issuance of the recent Security Council resolution, shows that the capital market is insured against such factors, and what affects the stock is the real sector of the economy and factors such as the profitability of companies and the situation of global markets, which at present have all had a positive effect on the capital market. 


\section{Suggestions:}

1. Investors in the stock market are recommended to invest in companies that have high quality earnings.

2. Investors should note that the quality of corporate earnings has an impact on the cost of capital. So that high-quality earnings are associated with lower cost of capital and low-income earnings with higher cost of capital.

3. The results of the third test, which examines the relationship between the quality of the audit and the cost of capital, with the two indicators of the size of the audit firm and the continuing cooperation of the audit firm with the client showed that the relationship is meaningful and responsive and showed that the large size of the audit firm increased audit quality. Therefore, companies use larger auditing institutions, as well as with the knowledge and awareness of institutions that can take measures to maintain co-operation in order to reduce their costs.

4. The positive trend of the stock exchange in the days when the stock market was adopted against the Security Council resolutions adopted in Iran in 2010, indicated that the sanctions had no effect on the stock market. What affects the stock market is the real sector of the economy and factors such as the profitability of companies that should be noted.

\section{References}

Alireza G.; Mojtaba Y. D. and Javad R.; Scientific Observer. (2016). Effect of sanctions on macroeconomic macroeconomics of Iran. Tehran: Institute for Business Studies and Research,

Ardestani, M. (2007). relationship between financial reporting quality and ownership costs; M.A thesis in Accounting; Alame Tabatabaei University

Ben-Hsien, B. and Da- Hsien, B. (2004). Income Smoothing. Earnings Quality and Firm Valuation Journal of Business Finance \& Accounting.

Chan, K. Chan,L. Jegadeesh, N. Lakinishok, J. (2005). earnings quality and stock returns", working paper university of Illinois at Urbana -Champaign-Department of Finance, vol.79; p.1041-1082.

Dan, 1.. (2010). Does auditor tenure affect accounting conservatism? Further evidence. Journal of Accounting Public Policy29, 226-241

De Angelo, L.E. (1981). Auditor size and auditor quality, Journal of Accounting and Economics, Vol. 3, 183-199

Defond, P.; D,Skinner. (2000). "Earnings management:reconciling the views of accounting academics,practitioners and regulators". Accounting Horizons.pp:235-250. 
Francies,I.Lafond, R.Olsson, P.Schipper, K. (2003). "The market pricing of accruals quality , Journal of Accounting and Economics, Vol.39,295-327

Francies, I.; Lafond, R.; Olsson, P.; Schipper, K. (2009). Earnings quality and the pricing effects of earnings patterns", working paper Duke University,vol.1; no.4 ;pp.259-340.

Frnado. A.. (2008). "Auditing Quality, Auditor Tenure, Client Importance,and Earnings management:An Additional Evidence". http://aaahq.org

Hajih, Z.; Sobhani, N. (2013). Investigating the Effect of Audit Quality on the Cost of Capital of Companies Accepted in the Stock Exchange. Number14.Pp.129-146.

Heydari A., Ahmadi. M. (2015). A Survey on the Relationship Between Earning Quality and Market Reaction to Changes in Cash Earning; Accounting and Audit Reviews; No. 37.

Jakson. H. J; Jacob, B., Jorgensen. N. (2007). "Earnings Attributes of Alternate Annual Reporting Periods". Financial Accounting and Reporting Section (FARS) Paper

Jan Jani Reza, Khodadadi Vali. (2011). Investigating the Relationship between Earnings and Its Components with Stock Returns with Emphasis on the Earnings Quality in Companies Accepted in the Tehran Stock Exchange, Journal of Accounting, Third Year, Spring, pp. 84113

Krishnan. Gopal,V. (2003). Does Big 6 Auditor Industry Expertise constrain Earnings Management?. Accounting Horizons.Vol 17.No1. pp:1-16.

Miho, Velenkis. \& Wong, T. (2002). "Why new issue and high-accrual firms underperform: The role of analysts credulity". The Review of Financial Studies". 15, Summer, 869-877.

Monssy, J. Leoneb, Charles E. Wasley. (2004)."Performance matched discretionary accrual measures". Journal of Accounting and Economics.39. 163-197.

Namazi, M.; Bayazdi, A.; Jabarzadeh Kangarloei, S. (2010). Investigate the relationship between audit quality and earning management. Accounting and Audit Research. second year. Number nine Spring 2011. Pp. 22-4.

Niko, M.; Hashem, N.; Iraj. Mehr Azin, A. (2009). Evaluation of accruals-based models for earning management discovery. Journal of Management Research. 20th edition. No. 82. Fall 2009. Pp. 20-1.

Nonahal Nahr, A.; Jabarzadeh, S.; Karimpour, Y. (2010). The Relationship Between Audit Quality and Reliability of Accruality. Accounting and Auditing Reviews. Volume 17. Number 61. Pages 55-70.

Osmani, M. Q.; (2002). determining cost of capital model and its effective factors; Ph.D thesis in accounting; Accounting and Management Faculty. Alame Tabatabaei University.

Kwon, S.; Y. (20(10. The quality of accruals and earnings: the role of accruals in estimation error". The Accounting Review.Vol 77. pp:35-59.

Stakes S., Shevlin, T., \& Tong, Y. (2009). "What is the information content of dividend changes?" Anew investigation of an old puzzle. Retrieved March 14, 2006,

Sufiani, A. (2005). relationship between economic value added and capital structure; M.A thesis. Al-Zahra University

Titman, S. B.T. (1986). "Information Quality and the Valuation of New Issues". Journal of Accounting Research.Vol 26 pp:127-132.

Wuchun, C. L.; Lei, L.; Mikhail, P. (2011).“Is Enhanced Audit Quality Associated with Greater Real Earnings Management? . Accounting Horizons, Vol. 25, No. 2, 83 -108.

Zengin, Y.; Serdar, O. (2010). audit quality and earnings management in interim financial reports". www.SSRN.com 